\title{
A Qualitative Assessment of Sponge-Feeding Organisms from the Mexican Pacific Coast
}

\author{
Verdín Padilla C.J.*, Carballo J.L. and Camacho M.L. \\ Laboratorio de Ecología del Bentos, Instituto de Ciencias del Mar y Limnología, Universidad Nacional Autónoma de \\ México, Estación Mazatlán, Avenida Joel Montes Camarena S/N, Apartado Postal 811, Mazatlán 82000, México
}

\begin{abstract}
Predation is one of the most important structuring mechanisms of benthic communities. The objectives of this study were to identify the main predators of sponges, and their principal prey, in two localities from the Sea of Cortez (Mexican Pacific Ocean). For this, 60 stomach contents were analyzed from 13 species of fishes, 23 species of opisthobranchs, and 4 species of echinoderms (urchins and starfishes). Two species of fish (Pomacanthus zonipectus and Holacanthus passer), and five species of opisthobranchs (Hypselodoris agassizii, Glossodoris sedna, Glossodoris dalli, Discodoris ketos and Tylodina fungina) included sponges in their diet. Sponge remains were not found in the echinoderm stomach contents. The two species of fish fed on 26 species of sponge; the most common were Haliclona caerulea and Spirastrella decumbens. The opistobranchs fed on 19 species, mostly Haliclona caerulea and Tethya taboga. In Mazatlán Bay there are 70 sponge species reported, and fishes and opisthobranchs feed on $46 \%$ of the species present, but predation seems to have little effect on distribution and abundance of sponges in this locality.
\end{abstract}

Keywords: Sponge, predation, Mexico, Pacific ocean, Haliclona caerulea.

\section{INTRODUCTION}

Sponges play an important role in benthic ecology as abundant, large, sessile filter-feeders [1, 2]. They are also notorious for having a very high variety of defence mechanisms and produce feeding-deterrent chemicals $[3,4]$. In addition, their tissue can contain high concentrations of silica spicules as structural components $[1,5]$. Thus, sponges do not seem to be a good food source for most organisms, because they are low in nutritional value, contain a lot of indigestible material, and are protected by chemical and physical means.

Previous studies have shown that neither the sharp needle-like structure of many spicules, nor the relative indigestibility of sponging deter feeding by some fishes and nudibranchs, which have evolved specialized mechanisms to be able to feed on sponges [5-8].

In fact, doridacean nudibranchs [9], together with some fishes (trunkfishes, angelfishes and filefishes) [5, 10-13], are important predators of sponges. The fishes that feed on sponges are thought to have evolved relatively recently, suggesting that competition forced them to eat a lesspreferred food source [14]. Nevertheless, the predation of sponges by fish has specialized to such an extent that they seem to be the only predatory organisms able to threaten sponge populations [15].

Other important organisms that feed on sponges are some species of echinoderms, such as Oreaster reticulates, which can eat large volumes of sponge in a short time [16].

*Address correspondence to this author at the Laboratorio de Ecología del Bentos, Instituto de Ciencias del Mar y Limnología, Universidad Nacional Autónoma de México, Estación Mazatlán, Avenida Joel Montes Camarena S/N, Apartado Postal 811, Mazatlán 82000, México; Tel: +52-669-9852845; Fax:+52-669-9826133; E-mail: aplycia@yahoo.com.mx
Hawksbill turtles also prey on sponges [17]. Very few papers have dealt with sponge-feeding fishes from the tropical Central Pacific [18, 19], or México [20].

This paper reports preliminary research on the factors shaping sponge assemblages along the Mexican Pacific Coast [21, 22]. Previous papers in this region [21-23] have been focused on physical factors or habitat type that explains the structure of sponge assemblages, but more information about the biotic factors controlling these assemblages is necessary. The aim of this paper was: 1) to determine the most important predators of sponges in two localities from Mexican Pacific Ocean, and, 2) to determine which sponges are consumed by these predators.

\section{MATERIALS AND METHODS}

\section{Study Area and Sampling Methodology}

The diet composition of fishes, opisthobranchs and echinoderms was studied by examining the gut contents of 60 specimens from two locations in the Sea of Cortez: Mazatlán Bay, Sinaloa: $23^{\circ} 12^{\prime} \mathrm{N}-106^{\circ} 24^{\prime} \mathrm{W}$, and Banderas Bay, Jalisco: $20^{\circ} 39^{\prime} \mathrm{N}-105^{\circ} 02^{\prime} \mathrm{W}$ ) (Fig. 1). In total, 13 species of fishes, 23 species of opisthobranchs, and 4 species of echinoderms (urchins and starfish) were examined. In addition, the diet of some opistobranchs was determined by in situ observations (Table 1).

The specimens were collected by SCUBA diving and snorkelling in the rocky subtidal zone. All fishes sampled were adults, and were caught by spear fishing. Opisthobranchs and echinoderms (starfish and sea urchins) were collected and placed in plastic bags.

In the laboratory, the stomachs and intestines of fishes were extracted and preserved in $4 \%$ formaldehyde. After 48 hours, they were transferred to $70 \%$ alcohol for preservation. 

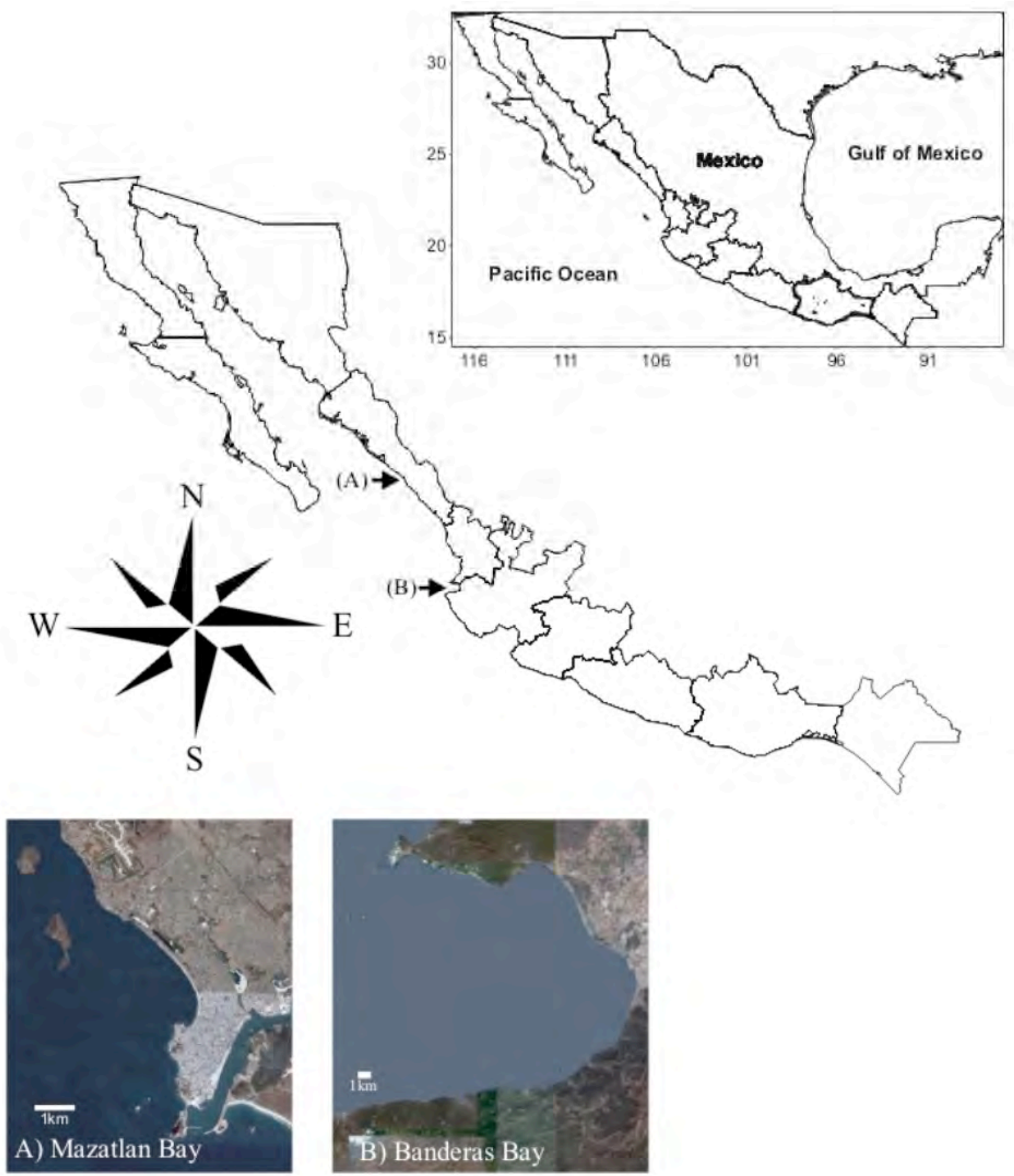

Fig. (1). Location of the study area in the Gulf of California. A) Mazatlán Bay (Sinaloa). B) Banderas Bay (Jalisco).

Subsequently, the stomach content was analyzed under a light microscope (OLYMPUS $\mathrm{CH} 30$ ) for the presence of spicules or sponging fibers. The sponges were identified considering the morphological characteristics and measurements of the skeletal structures [see method in 24].
To examine the diet of the opisthobranchs without killing them, the specimens were individually maintained in small 5 $\mathrm{ml}$ glass bottles with seawater until the specimens expelled their faeces. Once expelled, the faeces were analyzed under a microscope for the presence of sponge spicules [25]. In some 
Table 1. Species of Fishes, Opistobranchs and Echinoderms Analyzed for Stomach Contents. The Symbol (*) Indicates Remains of Sponges in the Content

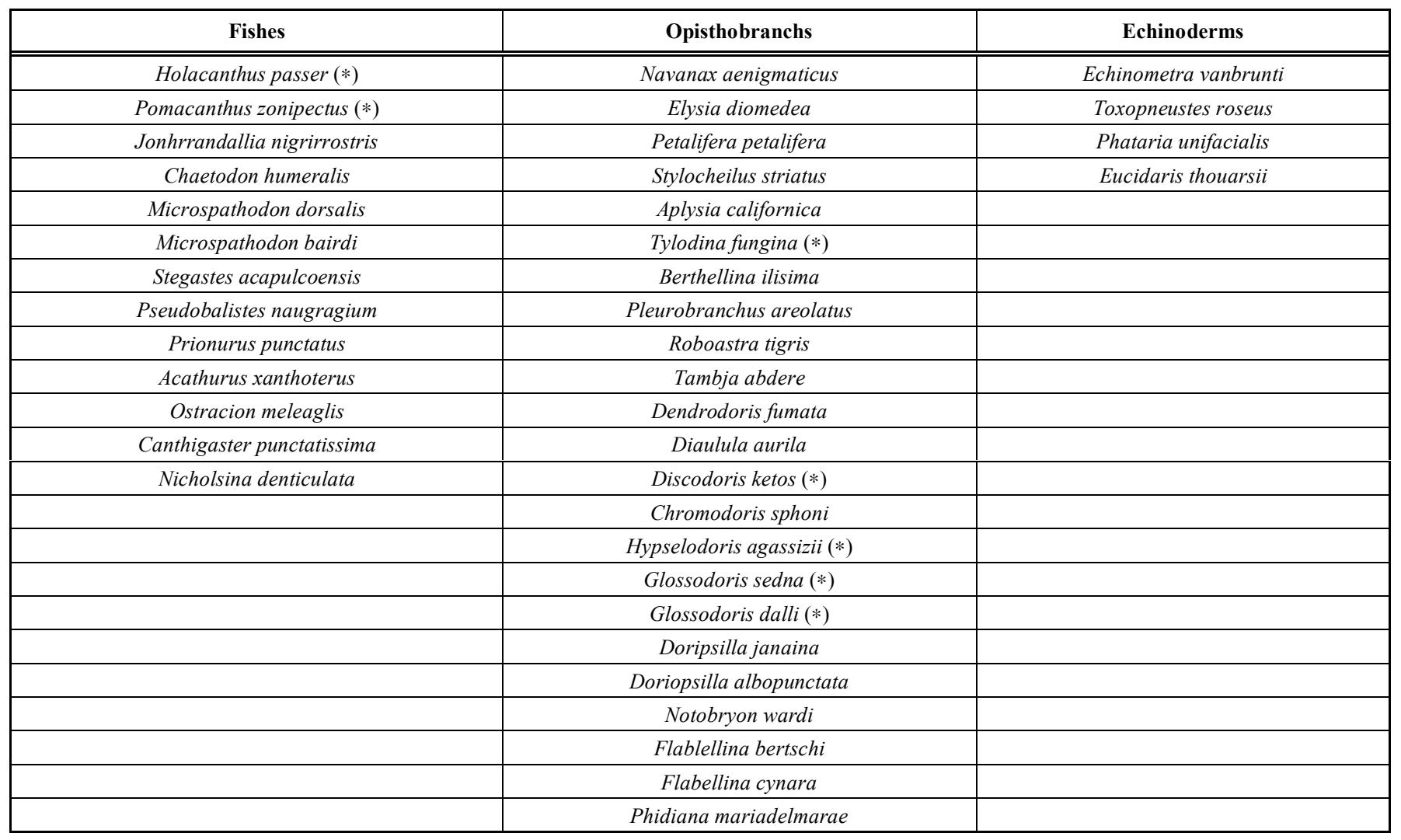

Table 2. Species of Sponges Consumed by Fishes and Opisthobranchs. The Letters BB and MB mean Banderas Bay and Mazatlán Bay, Respectively

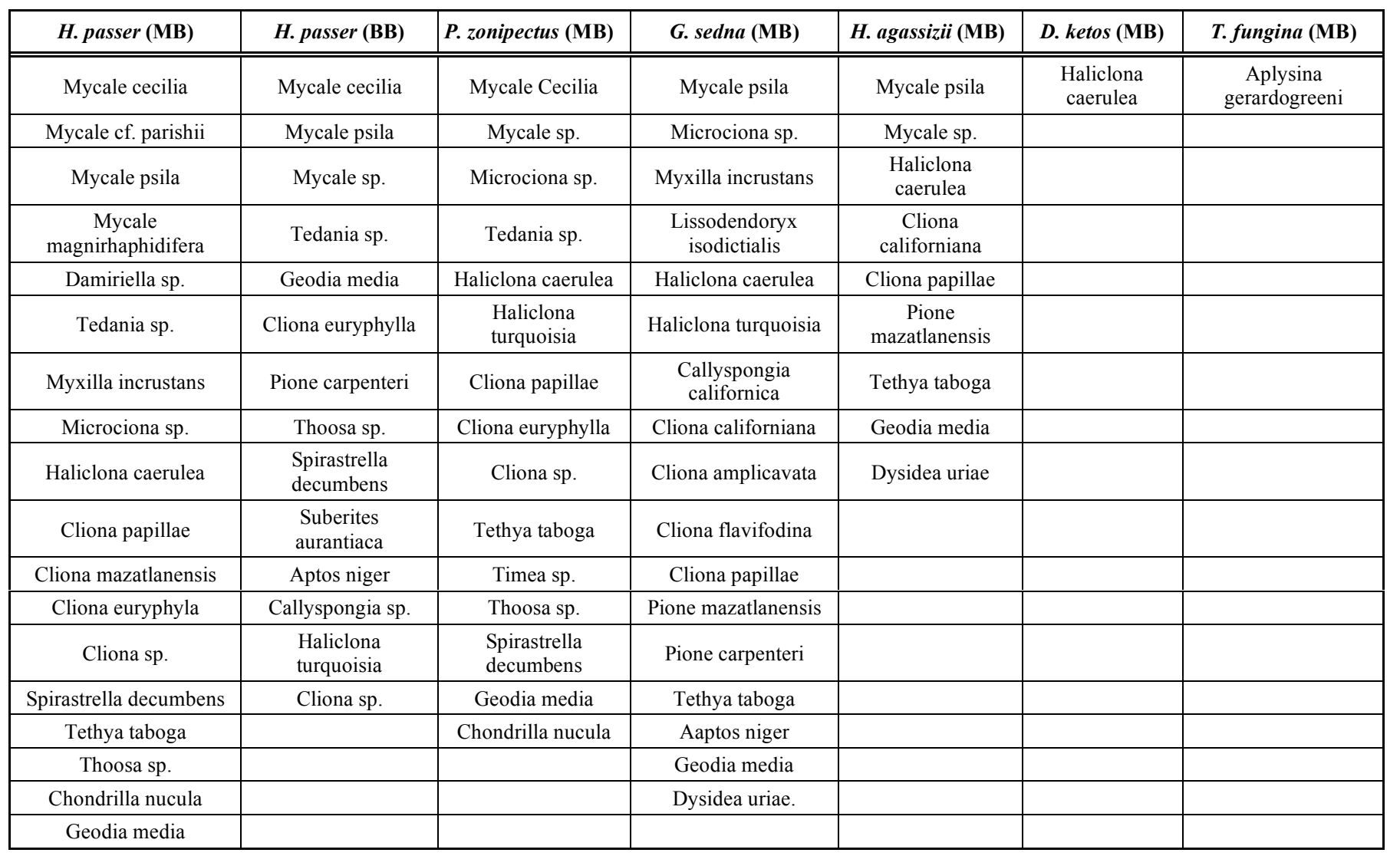


cases the diet of these opistobranchs was determined in situ through direct observations. The diet of $H$. agassizii, $G$. sedna and $G$. dalli was studied by stomach content and faeces, and the diet of D. ketos and T. fungina was determined by observations in situ (see results).

The percentage of occurrence, calculated using the data summation technique [26], was used to quantitatively characterize the diet. The number of stomachs in which each prey species occurred was counted and referred to as the total number of individuals examined. The same was done for the fishes (see Table 3 ).

\section{RESULTS}

We analyzed 23 species of opistobranchs belonging to 20 genera and 12 families, but sponge remains were only found in 5 species: Hypselodoris agassizii, Glossodoris sedna, Glossodoris dalli, Discodoris ketos and Tylodina fungina (Table 1, Table 2).

These five species fed on 19 species of sponge belonging to the orders Haplosclerida, Poecilosclerida, Hadromerida, Astrophorida and Verongida, although they showed preference for the order Hadromerida.
G. sedna had the highest polyphagous diet (16 prey species), feeding exclusively on spiculated demosponges, eight of them hadromerid species. H. agassizii also had a polyphagous diet consisting of nine species of demosponges, which included eight spiculated species, four of them hadromerids, and one horny sponge from the genus Dysidea (see Table 2). In contrast, D. ketos and T. fungina were much more selective, feeding exclusively on the sponges Haliclona caerulea and Aplysina gerardogreeni, respectively. The two sponges most frequently eaten by nudibranchs were Haliclona caerulea $(22.7 \%$ of the stomach contents) and Tethya taboga (18.2\% of the stomach contents) (Table 3).

In the case of the fishes, 13 species belonging to 12 genera and 6 families were analyzed, but only two of them, Pomacanthus zonipectus and Holacanthus passer (family Pomacanthidae) had sponge remains in their stomachs. Fishes were found to feed on sponges from 5 orders (Hadromerida, Haplosclerida, Poecilosclerida Astrophorida and Chondrosida), and like the nudibranchs they showed a preference for the sponges from the order Hadromerida; $P$. zonipectus included 8 species of hadromerids in its diet, and $H$. passer included 10. H. passer had the most polyphagous diet with 23 species, whereas $P$. zonipectus fed on 15 species, but the two species together fed on 24 sponge species. Haliclona caerulea and Spirastrella decumbens

Table 3. Frequency of Sponges Found in Gut Contents Expressed as Percentage (\%)

\begin{tabular}{|c|c|c|c|c|c|}
\hline Sponges & Fishes & Opisthobranchs & Sponges & Fishes & Opisthobranchs \\
\hline Order Astrophorida & & & Order Poecilosclerida & & \\
\hline Family Geodidae & & & Family Mycalidae & & \\
\hline Geodia media & 57.1 & 9.1 & Mycale cecilia & 71.4 & -- \\
\hline Order Hadromerida & & & Mycale psila & 28.6 & 9.1 \\
\hline Family Clionaidae & & & Mycale cf. parishii & 42.8 & -- \\
\hline Cliona papillae & 57.1 & 9.1 & Mycale magnirhaphidifera & 14.3 & -- \\
\hline Cliona amplicavata & -- & 4.5 & Mycale sp. & 42.8 & 4.5 \\
\hline Cliona flavifodina & -- & 4.5 & Microciona sp. & 57.1 & 4.5 \\
\hline Cliona californiana & -- & 9.1 & Family Myxillidae & & \\
\hline Cliona euryphylla & 57.1 & -- & Myxilla incrustans & 42.8 & 9.1 \\
\hline Cliona sp. & 42.8 & -- & Family Coelosphaeridae & & \\
\hline Pione mazatlanensis & 28.6 & 9.1 & Lissodendoryx isodictialis & -- & 4.5 \\
\hline Pione carpenteri & 14.3 & 4.5 & Damiriella $s p$. & 14.3 & -- \\
\hline Thoosa sp. & 71.4 & -- & Family Tedaniidae & & \\
\hline Thoosa mismalolli & 14.3 & -- & Tedania sp. & 71.4 & -- \\
\hline Family Spirastrellidae & & & Order Haplosclerida & & \\
\hline Spirastrella decubens & 85.7 & -- & Family Chalinidae & & \\
\hline Family Tethyidae & & & Haliclona caerulea & 85.7 & 22.7 \\
\hline Tethya taboga & 57.1 & 18.2 & Haliclona turquoisia & 28.6 & 4.5 \\
\hline Family Timeidae & & & Family Callyspongiidae & & \\
\hline Timea sp. & 42.8 & -- & Callyspongia californica & 14.3 & 4.5 \\
\hline Family Suberitidae & & & Order Verongina & & \\
\hline Suberites aurantiaca & 14.3 & -- & Family Aplysinidae & & \\
\hline Aptos cf. niger & 14.3 & 4.5 & Aplysina gerardogreeni & -- & 4.5 \\
\hline Order Chondrosida & & & Order Dictyoceratida & & \\
\hline Family Chondrillidae & & & Family Dysideidae & & \\
\hline Chondrilla nucula & 42.8 & -- & Dysidea uriae & -- & 4.5 \\
\hline
\end{tabular}


were found in $85.7 \%$ of the stomachs, followed by Mycale cecilia and Tedania sp. (both with 71.4\%) (see Table 3).

Four echinoderms belonging to four families, four genera and four species were analyzed as potential sponge feeders, but no remains of sponges were found in their guts.

\section{DISCUSSION}

Randall and Hartman [5] studied 212 species of fishes from the Caribbean, but only 11, which included angelfishes, trunkfishes, and filefishes, regularly fed on sponges. Our findings support these findings, since despite having analyzed only 13 species of fishes, the main sponge feeders were the angelfishes, $P$. zonipectus and $H$. passer. Indeed, the family Pomacanthidae is the most important family of spongivorous fishes, which contains the principal spongefeeding fishes in the Caribbean, particularly the genera Pomacanthus and Holacanthus [5, 12]. Others fishes such as Arothron hispidus, A. mappa and the butterflyfish Chaetodon ephippium have been reported as sponge-feeding from islands of the tropical Central Pacific [18, 27]. Bakus [19] also increased the list of potential sponge feeders to include goat fish, parrot fish, butterfly fish and trigger fish, since he found sponge spicules in the gut contents of Chaetodon auriga, Ctenochaetus striatus, Lutjanus bohar, and Rhinecanthus aculeatus. We also analyzed species similar to some of these groups, such as Chaetodon humeralis, but we did not find sponge remains in the stomach contents. Thus, the presence of some sponge spicules in the digestive tract does not necessarily imply that a fish feeds intentionally on sponges. Sponges spicules are often a component of the inorganic sediment and may be ingested accidentally with the prey or incidentally with detritus [5].

For angelfishes, it known that sponges make up a large part of their diet [14]. In a previous study sponges comprised over $95 \%$ of the food of angel fish of the genus Holacanthus, over $70 \%$ of the food of the genus Pomacanthus, and more than $85 \%$ of the food of the filefish Cantherhines macrocerus $[5,14,28,29]$. Pomacanthus arcuatus for example, live as mating pairs in large territories, and they move and feed slowly, taking 3-4 bites per minute. Sponges make up $70 \%$ of their diet with the rest of their diet consisting of gorgonian polyps, other invertebrates, and algae. Although algae make up only $10 \%$ of their diet, foraging for algae takes up about a third of their foraging time [14].

Pérez-España \& Abitia-Cárdenaz [20] suggested that $P$. zonipectus and $H$. passer are generally omnivorous with adaptations for herbivory, but we don't agree, since according to our results $P$. zonipectus and $H$. passer are mainly spongivores. The diet of the Queen Angelfish (Holocanthus ciliaris) is made up almost entirely of sponges (97\%), with the balance made up of algae and invertebrates. French Angelfish (Pomacanthus paru) forage in a similar manner, but they consume less gorgonian polyps and algae. Rock Beauties (Holocanthus tricolor) also eat mostly sponges, making up $96 \%$ of their diet, although half of their foraging time is spent scraping algae off of rocks [14]. It seems that the diet of these species relates to the availability of food in their local habitat. Interestingly, all these species prefer to feed on sponges with comparatively low spicule content [14], and our results support this, since angelfishes from the
Sea of Cortez fed preferably on hadromerid sponges possibly because these species are easier to digest than sponges from the order Poecilosclerida [30, 31]. Juveniles of the angelfish are also generalists in the consumption of sponges, presenting a diet similar to that of the adult. Thus, 34 species of sponges were found in the gut contents of juveniles of the angelfish Pomacanthus paru, Holacanthus ciliaris and Holacanthus tricolor in Salvador, Bahia state (Brazil). However, the juveniles of these species, consume poecilosclerid sponges (such as Tedania ignis and Mycale sp.), together with hadromerids (such as Spirastrella $\mathrm{sp}$.), all with $37.5 \%$ of frequency [40].

Regarding opisthobranchs, it is important to highlight the presence of highly specialist species such as Tylodina fungina, whose diet is based completely on the sponge Aplysina gerardogreeni. These kinds of species that spend their entire life on the sponge, which serves as a shelter, food source or provides protection against predators, appear to be very common in the genus Tylodina [32].

Irrespective of the species considered within the genus Tylodina, which seem to feed exclusively on the sponges from the genus Aplysina [32], Discodoris ketos could be considered another highly specialist species, because it was always found living over or under the sponge Haliclona caerulea, even taking the coloration of its prey and this is one of the most abundant sponges in the rocky coast of Mazatlán [33] (See Fig. 2).

In Mexico, Hochlowski et al. [34] (Nayarit, Mexican Pacific Ocean) suggested that the nudibranch Hypselodoris agassizii fed on the sponge Euryspongia sp. (probably a Dysidea sp.), because we found that the same species feeds on Dysidea uriae. In fact, the species from the genus Hypselodoris display a high specificity for sponges of the family Dysidea. Other Dorids, such as Glossodoris dalli from Costa Rica, also feed on the horny sponge Hyrtios erecta [35]. Dorids studied in the Gibraltar Strait (Spain) feed mainly on sponges of the genera Mycale, Myxilla, Cliona and Geodia [9]. The fact that nudibranchs feed mainly on sponges of the order Hadromerida in Mazatlan Bay may be because these species are easier to digest than sponges of the order Poecilosclerida [30, 31].

Fishes together with opisthobranchs fed on 32 species of sponges, from 5 orders. In Mazatlán Bay $\sim 70$ sponge species have been reported [36] and the two groups (opisthobranchs and fishes) eat $46 \%$ of the species of sponges present in those bays. The four sponges most eaten by both predators were H. caerulea, G. media, T. taboga and Microciona sp., which are some of the most abundant species sponges in Mazatlán Bay [21, 33, and other papers of the group].

In coral reefs sponges are often confined to cryptic habitats, and when they are exposed to potential predators they are consumed rapidly $[12,19]$, even by fishes that are generally considered herbivores, primarily parrot fishes of the genus Sparisoma [13]. Sponge remains were not found in the echinoderm stomach contents, but sea-stars are the dominant spongivores in Antarctic benthic communities [38], and in subtidal regions from south-eastern Australia sea urchins such as Centrostephanus rogersii are the dominant grazers feeding on sponges in addition to consuming a broad range of algae [39]. 

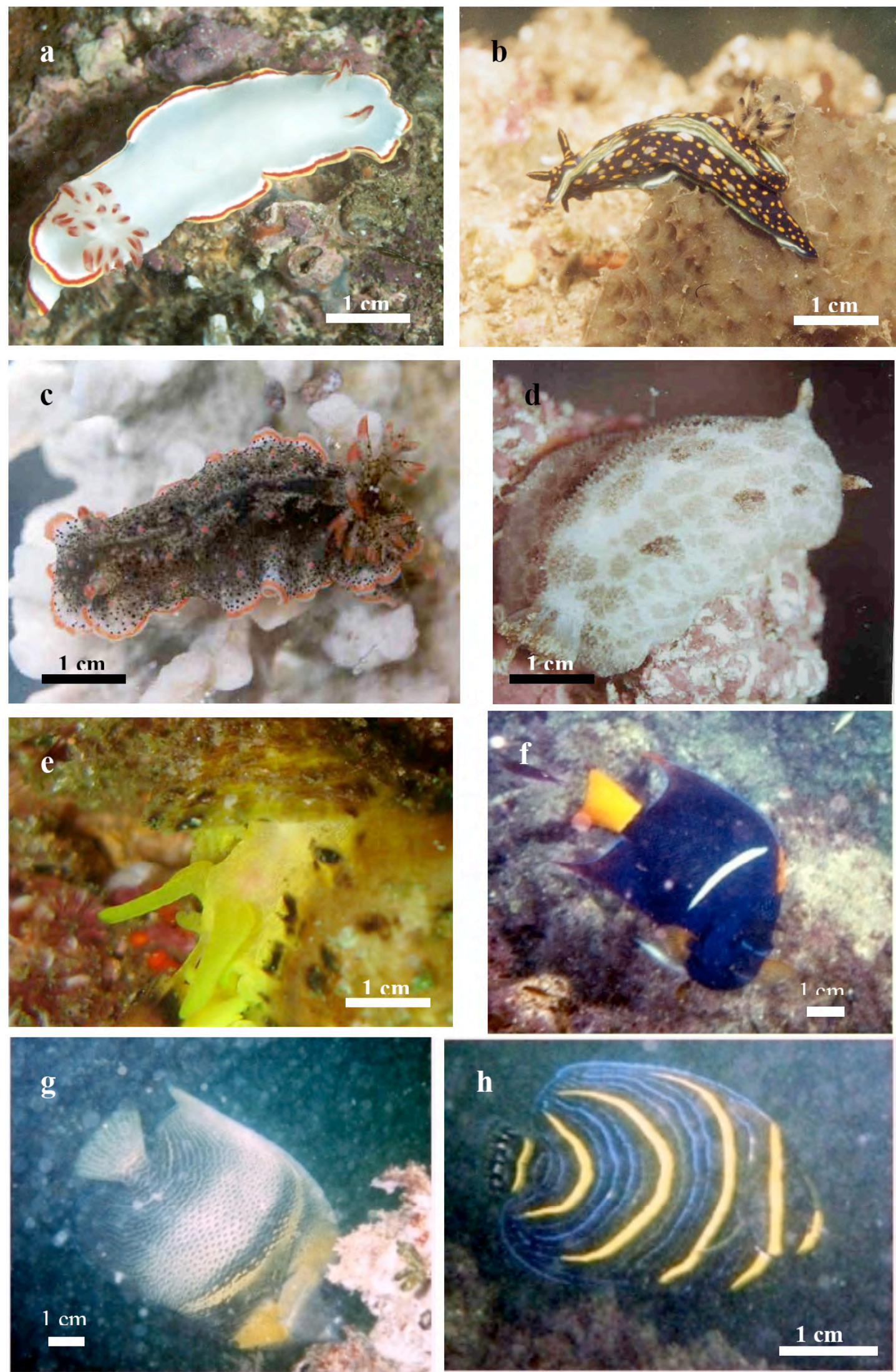

Fig. (2). Underwater photography of sponge-feeding nudibranchs and fishes from the Sea of Cortez (by JL Carballo) (a) Glossodoris sedna, (b) Hypselodoris agazzisii on Dysidea uriae, (c) Glossodoris dalli, (d) Discodoris ketos, (e) Tylodina fungina on Aplysina gerardogreeni, (f) Holacanthus passer, (g) Pomacanthus zonipectus adult and juvenile, (h). 
A few species of opisthobranch seem to have the ability to control some sponge population [37], such as Tylodina species, which consume mainly sponges of the genus Aplysina. However, most of the studies [3-5,12], and ours own data, did not show strong evidence that that sponge predation was a significant factor that limits sponge distribution and diversity.

\section{ACKNOWLEDGEMENTS}

We are grateful to the following sources of funding: CONABIO FB666/S019/99, CONABIO FB789/AA004/02, CONABIO DJ007/26, and CONACYT SEP-2003-C0242550. This work was carried out with permission of SAGARPA (Permit numbers: DGOPA.02476.220306.0985 and DGOPA.06648.140807.3121). We thank Clara Ramírez Jáuregui for help with the literature.

\section{REFERENCES}

[1] Sarà M, Vacelet J. Ecologie des Démosponges. Spongiaires. Traité de Zoologie. In: Gras P, Ed. Paris: Masson 1973; Vol. 3(1): pp. 462-576.

[2] Bell JJ. The functional roles of marine sponges. Estuar Coast Shelf Sci 2008; 79: 341-53.

[3] Pawlik JR, Chanas B, Toonen RJ, Fenical W. Defenses of Caribbean sponges against predatory reef fish. I. Chemical deterrency. Mar Ecol Prog Ser 1995; 127: 183-94.

[4] Faulkner DJ. Highlights of marine natural products chemistry (1972-1999). Nat Prod Rep 2000; 17: 1-6.

[5] Randall JE, Hartman WD. Feeding fishes of the West Indies. Mar Biol 1968; 1: 216-25.

[6] Chanas B, Pawlik JR. Defenses of Caribbean sponges against predatory reef fish. II. Spicules, tissue toughess, and nutritional quality. Mar Ecol Prog Ser 1995; 127: 195-211.

[7] Waddell B, Pawlik JR. Defenses of Caribbean sponges against invertebrate predators: I. Assays with hermit crabs. Mar Ecol Prog Ser 2000a; 195: 125-32.

[8] Waddell B, Pawlik JR. Defenses of Caribbean sponges against invertebrate predators: II. Assays with sea stars. Mar Ecol Prog Ser 2000b; 195: 132-44.

[9] Megina C, Carballo JL, Cervera JL, García-Gómez JC. The diet of Platydoris argo (Gastropoda: Nudibranchia) and the dietary specialization of sponge eating dorids. J Molluscan Stud 2002; 68: 173-9.

[10] Hartman WD. Form and distribution of silica in sponges. In: Simpson TL, Volcani BE, Eds. Silicon and siliceous structures in biological systems. Berlin Heidelberg New York: Springer 1981; 454-93.

[11] Wainwright SA, Biggs WD, Currey JD, Gosline JM. Mechanical design in organisms. Princeton: Princeton University Press 1982.

[12] Wulff JL. Sponge feeding by Caribbean angelfishes, trunkfishes, and filefishes. In: van Soest RWM, van Kempen TMG, Braekman J-C, Eds. Sponges in Time and Space, A. A. Balkema/Rotterdam/ Brookfield 1994; 265-71.

[13] Wulff JL. Parrotfish predation on cryptic sponges of Caribbean coral reefs. Mar Biol 1997; 129: 41-52.

[14] McGinley M. "Coral reef fish feeding behavior in the Caribbean." In: Cutler J, Cleveland, Eds. Encyclopedia of Earth. (Washington, D.C.: Environmental Information Coalition, National Council for Science and the Environment) 2008.

[15] Hoppe WF. Growth, regeneration and predation in three species of large coral reef sponges. Mar Ecol Prog Ser 1988; 50: 117-25.

[16] Wulff JL. Sponge-Feeding by the Caribbean starfish Oreaster reticulatus. Mar Biol 1995; 123: 313-25.
[17] Meylan A. Spongivory in Hawksbill Turtles: a diet of glass. Science 1988; 22(239): 393-5.

[18] Dawson RMC, Elliott DC, Elliott WH, Jones KM, Eds. Data for Biochemical Research, NY: Oxford University Press 1955; pp. 426-48.

[19] Bakus GJ. The feeding habits of fishes and primary production at Eniwetok, Marshall Islands. Micronesia 1967; 3: 135-49.

[20] Perez-España H, Abitia-Cardenas LA. Description of the digestive tract and feeding habits of the king angel fish and the Cortez angelfish. J Fish Biol 1996; 48: 807-17.

[21] Carballo JL, Vega C, Cruz-Barraza JA, et al. Short and long-term patterns of sponge Diversity on rocky tropical coast: evidence of large structuring factors. Mar Ecol-Evol Persp 2008a; 29: 216-36.

[22] Carballo JL, Cruz-Barraza JA, Nava H, Bautista-Guerrero E. Esponjas perforadora de sustratos calcáreos. Importancia en los ecosistemas arrecifales del pacífico este, 1st ed. México: Comisión Nacional para el Conocimiento y Uso de la Biodiversidad (CONABIO), 2008b.

[23] Carballo JL, Bautista-Guerrero E, Leyte-Morales GE. Boring sponges and the modelling of coral reefs in the East Pacific Ocean. Mar Ecol Prog Ser 2008c; 356: 113-22.

[24] Carballo JL, Nava H. Comparison of sponge assemblage patterns between two adjacent tropical rocky habitats (tropical pacific ocean, México). Ecoscience 2007; 14(1): 92-102.

[25] Gemballa S, Schermutzki F. Cytotoxic haplosclerid sponges preferred: A field study on the diet of the dotted sea slug Peltodoris atromaculata (Doridoidea: Nudibranchia). Mar Biol 2004; 144: 1213-22.

[26] Da' Cunha AB, Shehata AM, De Oliveira W. A study of the diets and nutritional preferences of tropical species of Drosophila. Ecology 1957; 38(1): 98-106.

[27] Hiatt RW, Strasburg DW. Ecological relationships of the fish fauna on coral reefs of the Marshall Islands. Ecol Monograph 1960; 30(1): 65-127.

[28] Reynolds WW, Reynolds LJ. Observations of food habitats of the angelfishes Pomacanthus zonipectus and Holacanthus passer en the Gulf of California. Calif Fish Game 1971; 124-25.

[29] Hourigan TF, Stanton FG, Kelley CD, Carlson B. The feeding ecology of three species of Caribbean angelfishes (family Pomacanthidae). Environ Biol Fish 1989; 24: 105-16.

[30] Bloom SA. Morphological correlations between dorid nudibranch predators and sponge prey. Veliger 1976; 18: 289-301.

[31] Bloom SA. Specialization and noncompetitive resouerce partitioning among sponge-eating dorid nudibranchs. Oecologia 1981; 49: 305-15.

[32] Becerro MA, Turon X, Uriz MJ, Templado J. Can a sponge feeder be a herbivore? Tylodina perversa (Gastropoda) feeding on Aplysina aerophoba (Demospongiae). Biol J Linnean Soc 2003; 78: 429-38.

[33] Carballo JL, Ávila E. Population dynamics of a mutualistic interaction between the sponge Haliclona caerulea, and the red alga Jania adherens. Mar Ecol Prog Ser 2004; 279: 93-104.

[34] Hochlowski JE, Walker RP, Ireland C, Faulkner DJ. Metabolites of Four Nudibranchs of the Genus Hypselodoris. J Org Chem 1982; 47: 88-91.

[35] Fontana A, Mollo E, Ortea J, Gavagnin M, Cimino G. Scalarane and Homoscalarane compounds from the nudibranchs Glossodoris sedna and Glossodoris dalli: Chemical and biological properties. J Nat Prod 2000; 63: 527-30.

[36] Cruz-Barraza JA. Taxonomía y distribución de las esponjas marinas (Porifera: Demospongiae) del Pacifico Mexicano. Mexico: Universidad Nacional Autónoma de México 2008; p. 570.

[37] Elvin DW. Feeding of a dorid nudibranchs, Diaulula sandienguesis on the sponge Haliclona permollis. Veliger 1976; 19: 194-8.

[38] Furrow FB, Amsler CD, McClintock JB, Baker BJ. Surface sequestration of chemical feeding deterrents in the Antarctic sponge Latrunculia apicalis as an optimal defense against sea star spongivory. Mar Biol 2003; 143: 443-9. 
[39] Wright JT, Benkendorff K, Davis AR. Habitat associated differences in temperate sponge assemblages: the importance of chemical defense. J Exp Mar Biol Ecol 1997; 213: 199-13.

[40] Bárbara R, A, Batista D, Sampaio CLS, Muricy G. Spongivory by juvenile angelfish (Pomacanthidae) in Salvador, Bahia State,
Brazil. Porifera research: In: Custódio MR, et al., Eds, Porifera Research. Biodiversity, innovation and sustainability, 2007; 13137.

Received: May 30, 2009

Revised: October 15, 2009

Accepted: November 01, 2009

(C) Verdín et al.; Licensee Bentham Open.

This is an open access article licensed under the terms of the Creative Commons Attribution Non-Commercial License (http://creativecommons.org/licenses/by$\mathrm{nc} / 3.0 /$ ), which permits unrestricted, non-commercial use, distribution and reproduction in any medium, provided the work is properly cited. 